Rollnik-Sadowska E., The selected issues of labour market policy in Germany - implementation possibilities in Poland, „Economics and Law”, Polszakiewicz B., Boehlke J. (ed.), Vol. 13, No. 1/2014, pp. 59-70. DOI: http://dx.doi.org/10.12775/EiP.2014.005.

\author{
EWA ROLLNIK-SADOWSKA*
}

\title{
THE SELECTED ISSUES OF LABOUR MARKET POLICY IN GERMANY \\ - IMPLEMENTATION POSSIBILITIES IN POLAND
}

\author{
SUMMARY
}

The author in the article presents the conditionings and the main changes introduced through labour market reforms implemented in Germany since the activity of the Hartz Commission. There were presented the components of all four Hartz Reforms and the directions of its continuation after 2005. The aim of the publication is to determine, which of the German solutions are possible to implement in the Polish economic and social conditionings.

The research method undertaken in that paper was the analysis of secondary data - both statistical as well as reports and publications connected with German labour market policy.

Keywords: labour market policy, the Hartz Reforms, unemployment JEL Classification: J08, J68, J88

"Ewa Rollnik-Sadowska, Bialystok University of Technology, Faculty of Management, Dapartment of Economics and Social Sciences, ul. O. Tarasiuka 2, 16-001 Kleosin, phone: +48 660759 656, e-mail: e.rollnik@pb.edu.pl.

$\diamond \mathrm{S} / \mathrm{WZ} / 3 / 12$. 


\section{INTRODUCTION}

In the literature, there are determined four different models of labour market policy - Scandinavian, liberal, Mediterranean and corporate. The rules gathered in those regimes assume different attitude toward the scope of the welfare state, the degree of commercialization of labour market services, rules for the granting of benefits, as well as the role of trade unions.

The Scandinavian (Nordic) model provides a high degree of self-regulation for bargaining parties. The role of the state is limited. Traditionally, bargaining parties have been given the right to make their own rules for governing the labour market. Hence, legislation provides only a framework for regulations and rules arbitrated by collective agreements ${ }^{1}$.

The liberal (Anglo-Saxon) model, presents a more marketbased view of the labour market. This model is connected with a classical liberal philosophy of small government and applies less comprehensive welfare. There are low levels of labour force coverage under collective agreements, just as there are low levels of membership in unions and employers' organizations. Moreover, this model is founded on common law rather than legislation, and the notion of a flexible labour market ruled by price mechanisms, along with a small amount of regulation. Greater freedom is provided to individual employers to hire and fire personnel, to set pay and define terms of employment and to determine working conditions, which allows for higher business efficiency and higher productivity.

The Mediterranean (or Latin) model is based on Romano-Germanic legal systems (the same as corporate model) and emphasizes that labour is different from a normal commodity. In that model the state plays an important role due to the fact that the bargaining parties have less coverage and are more divided. Commonplace features of relations between bargaining include high levels of industrial conflict and highly politicized, internally divided labour unions. Bargaining agreement coverage is upheld by employers' associations as well as legal extensions of collective agreements to non-union workers and firms².

German labour market policy represents the corporate (continental) model. In that model, the state plays a large role, and legislation is the most

${ }^{1}$ N. Karlson, H. Lindberg, Corporate cartels and challenges to European labour market models, „Revista Internacional de Organizaciones”, No. 9/2012, p. 13.

${ }^{2}$ Ibidem, p. 14. 
prominent regulatory instrument. However, bargaining between the parties and collective agreements are still important features. The German model's is also characterized by active labour market programs to ameliorate the effect of structural changes in the economy, high protection of workers' rights and a wide range of the unemployed security ${ }^{3}$.

Germany is also known from the adjustment of the educational system to the needs of the labour demand by widely spread system of dual learning, which is also very important to decrease the youth unemployment ${ }^{4}$.

On the other hand, Germany, although characterized by the strong economy based on production and the trade surplus ${ }^{5}$ with one of the best worldwide infrastructure ${ }^{6}$ and research-intensive industries ${ }^{7}$, also suffered from high unemployment as well as professional inactivity, both of which burdened public finances. Those factors, simultaneously with a scandal involving the federal employment office ${ }^{8}$, forced German government to start a series of rather radical - given the prior reluctance - social policy changes called Hartz reforms.

The Hartz reforms in their entirety seem to have contributed to a better functioning of the German labour market and the effectiveness of specific active labour market policies.

Nowadays in Europe, eight years after the German reforms of labour market, new economic problems occurred as results of global financial crisis. However, the indicators of the German labour market seem to be stable, which proves the effectiveness of conducted policy, as well as relatively bal-

${ }^{3}$ I.M. Smandek, K. Nagel, Polityka rynku pracy i źródta jej finansowania, Wydawnictwo Uniwersytetu Ekonomicznego w Katowicach, Katowice 2010, p. 38-39.

4 There is in Germany one of the lowest youth unemployment rates in the EU-27, which was $9,9 \%$ in 2010 (21,1\% in the EU-27) and it decreased to 8,1\% in 2012 (increased to 22,8\% in the EU-27). Eurostat, http://epp.eurostat.ec.europa.eu (08.07.2013).

${ }^{5}$ In 2011, German GDP reached 20\% of total GDP for the EU-27. Germany Trade\&Invest, Economic Overview Germany: Market, Productivity, Innovation, Issue 2013, Berlin 2012.

${ }_{6}$ The 2012-2013 Global Competitiveness Report of the World Economic Forum ranked Germany first in Europe and third worldwide for infrastructure; singling out Germany's extensive infrastructure for highly efficient transportation of goods and passengers for special praise. Accumulated in this score for Germany are high marks for the quality of roads and air transportation, excellent railroads and port infrastructure, as well as its communications and energy infrastructure.

${ }^{7}$ In 2010, Germany exported high-tech goods to the value of EUR 120 billion - making it the top high-tech goods exporter in Europe and second worldwide. Germany Trade\&Invest, Economic Overview..., op. cit.

${ }^{8}$ The federal employment office was accused of massive fraud in the reporting of successful job placements. L. Jacobi, J. Kluve, Before and after the Hartz reforms: the performance of active labour market policy in Germany, Forschungsinstitut zur Zukunft der Arbeit, Discussion, Paper No. 2100/2006, p. 2. 
anced labour demand. That is why it is worth to analyze the solutions implemented in Germany to improve the situation in domestic labour market.

The objective of this paper is to present the main assumptions of the Hartz reforms and its continuation in the last eight years. Moreover the author proposes, which solutions of German social policy can be implemented in Poland in regard to Polish social and economic conditionings.

The research method undertaken in that paper was desk-research of secondary data as reports and publications connected with German labour market policy as well as statistical data.

\section{THE HARTZ' REFORMS}

The Hartz' Commission, ruled by the chair - Peter Hartz ${ }^{9}$, was set up in 2002 to modernise German labour market institutions. In 2002 the unemployment rate in Germany reached 8,7\%, which was the comparable level as the average for the EU-27 $(8,9 \%)^{10}$. Public labour market institutions are not responsible for the phenomenon of mass unemployment in Germany, but the improvement of their efficiency, in times of economic decline, can contribute to the unemployment reduction ${ }^{11}$. The suggestions of the comission led to four laws, which came into force in three waves: Hartz I and II were implemented in January 2003, Hartz III - in January 2004, Hartz IV in January $2005^{12}$. Each of the above stages consisted of several components - see table 1.

As can be seen from the above Table, The Hartz reforms intervened in many fields of German both passive and active labour market policy.

As it was mentioned, the main objective of the reform was to improve the performance of placement services and policy programmes mostly by introducing market mechanisms to the realm of placement services and by streamlining public employment services. Furthermore, cost-effectiveness in

9 Peter Hartz was the human resources executive at Volkswagen. He became notable as adviser to German chancellor Gerhard Schröder, for whom Hartz developed the described reforms.

${ }^{10}$ Eurostat, http://epp.eurostat.ec.europa.eu (19.07.2013).

${ }^{11}$ J. Nadolska, Rynek pracy w procesie przekształceń państwa socjalnego we wspótczesnych Niemczech, Oficyna Wydawnicza ASPRA-JR, Warszawa 2010, p. 157.

${ }^{12}$ H. Räisänen, J. Alatalo, K. Krüger Henriksen, T. Israelsson, S. Klinger, Labour Market Reforms and Performance in Denmark, Germany, Sweden and Finland, Employment and Entrepreneurship 19/2012, Ministry of Employment and the Economy, Helsinki 2012, p. 23. 
the specific context of each regional labour market is targeted to be the key criteria when choosing programme contents and participants ${ }^{13}$.

Table 1. Components of the Hartz' Reforms

\begin{tabular}{|c|c|}
\hline REFORMS' STAGE & COMPONENTS \\
\hline \multirow{5}{*}{ Hartz I } & $\begin{array}{l}\text { implementation of Personal-Service-Agentur (PSA) (temporary work agencies for the unemploy- } \\
\text { ed), }\end{array}$ \\
\hline & modified claims - changes to when and how often the unemployed have to register, \\
\hline & stricter sanctions for the unemployed in case of luck of cooperation with the placement officer, \\
\hline & introduction of training vouchers for the unemployed, \\
\hline & legal employment protection only for firms with ten or more employees (previously with five). \\
\hline \multirow{2}{*}{ Hartz II } & implementation of Minijobs and Midijobs with the reduced social security contributions, \\
\hline & a new type of start-up subsidy (Ich-AG). \\
\hline \multirow[t]{2}{*}{ Hartz III } & $\begin{array}{l}\text { reorganisation of German Public Employment Services: the Federal Employment Agency and lo- } \\
\text { cal job centres, }\end{array}$ \\
\hline & emphasis on the individual work with the longterm unemployed - the role of case managers. \\
\hline Hartz IV & reform of unemployment benefit and social assistance system. \\
\hline
\end{tabular}

Source: Räisänen H., Alatalo J., Krüger Henriksen K., Israelsson T., Klinger S., Labour Market Reforms and Performance in Denmark, Germany, Sweden and Finland, Employment and Entrepreneurship 19/2012, Ministry of Employment and the Economy, Helsinki 2012, p. 24; A. Kemmerling, 0. Bruttel, New politics in German labour market policy? The implications of the recent Hartz reforms for the German welfare state, Wissenschaftszentrum Berlin für Sozialforschung, Discussion Paper SP I 101/2005, p. 3.

As a effect of the reform the former employment offices were converted into costumer-orientated one-stop-centres. The results of research indicate positive impact of one-stop-centres on the integration into regular employment ${ }^{14}$.

The second aspect of changes in area of organizational structure was introduction of market forces to labour market services. The authors of the reform created, for instance, voucher systems for placement services and training measures. Each individual, whom the public employment service was unable to place after six weeks of unemployment, can choose an alternative private placement service. The private service receives a lump sum payment after having placed the jobseeker successfully. Providers of training measures also can be chosen freely by the client and paid for with a voucher. For placement vouchers, the results of research fail to find any significant effect on the pros-

${ }^{13}$ L. Jacobi, J. Kluve, op. cit., p. 8.

${ }^{14}$ Ibidem, p. 15. 
pect of entering employment. It appears that many clients who had received placement vouchers did not actually use them ${ }^{15}$.

Moreover, the public employment institutions can choose to outsource services fully or partly, most importantly placement services. For example local employment office either may contract a private temporary work agency or, if no provider is available, may run a PSA by itself ${ }^{16}$.

The Hartz reform also shifts priority towards active measures that require proactive behaviour of the unemployed and promote their direct integration into regular employment. To this end, the reform re-designed integration subsidies, introduced new forms of wage subsidies, start-up subsidies and jobs with reduced social security contributions. Many active policy measures were re-designed in terms of their target population. Thanks to the unemployed profiling, specific active labour market programs have been offered for those with the highest probability of finding a job after the measure. Active measures, which represent the best the new activation strategy, are start-up subsidies ${ }^{17}$. The unemployed can get the grant for own company creation, after acceptation of business plan by the representative of the chamber of commerce. The reform introduced also an alternative subsidy, the so-called IchAG, which is independent of prior social security contributions.

Moreover, there were implemented by the Hartz reform the so-called "Minijobs" and "Midijobs". A person holding a Minijob (income below 450 EUR per month or the employee only working a maximum of 50 days per year) is exempted from social security contributions, which effectively increases net wages. People who practice Midijobs (with incomes between 450.01 and 850 EUR) are allowed to get social security subsidies, which are paid at a decreasing rate, depending on the income.

Furthermore, the core element of the Hartz reforms is the principle of "rights and duties". It means that the access to benefits and active labour market participation is strictly conditional on a person's ability to work (which is at least 15 hours per week ${ }^{18}$ ).

The reform also introduced sanction elements, which are connected with monitoring of search activities of the unemployed and their personal efforts to re-integrate into the labour market ${ }^{19}$.

15 Ibidem.

${ }_{16}$ Ibidem, pp. 8-9.

17 The evaluation results proved that start-up subsidies had a significant positive effect at a aggregate level. H. Räisänen, J. Alatalo, K. Krüger Henriksen, T. Israelsson, S. Klinger, op. cit., p. 28.

18 Ibidem, p. 10.

19 For example the jobseeker is obliged to accept any offer of suitable work, which also means to move to different city under certain circumstances. 
What's more, the reform also assumes the support of the unemployed, who come back to professional activity, and presumably represent lower productivity, by several forms of wage subsidies which are paid to employers when hiring a certain type of hard-to-place worker.

The last area of the Hartz reforms was deregulation of labour market institutions, which took place regarding temporary work agencies (the restrictions were abolished), dismissal protection and the regulation of fixed-term contracts.

A new important rule was introduced in the activity of temporary work agencies requiring that such an agency must either guarantee equal pay and equal treatment of temporary workers and regular workers or join a collective bargaining agreement between trade unions and employers ${ }^{20}$.

At the same time, the wage setting process, has remained highly centralised (the minimum wages are often set by collective bargaining agreement in the separate sectors of the economy and separate lands).

\section{GERMAN LABOUR MARKET POLICY AFTER THE HARTZ REFORMS}

After the Harts reforms, which set up the general pattern of German social policy with modernised labour market institutions, further adjustments took place. In 2009 new measures for activation and reintegration were formed. The basic idea was to increase responsibility for local agencies, as the institutions with the best knowledge about problems of local labour market, which can undertake appropriate measures and actions ${ }^{21}$.

One of the effect of the Hartz reforms was the decrease of the entitlement period to unemployment benefit $\mathrm{I}^{22}$, but the political pressure caused the government to prolong the entitlement in 2008.

As it was mentioned in the introduction, one of the objectives of German social policy is the reduction of structural unemployment, improving the employability of the youths and overcoming the NEETS problems (young people who are not in education, employment, or training) by creation of educational system adjusted to labour market demands. In 2008, a new law came

\footnotetext{
${ }^{20}$ L. Jacobi, J. Kluve, op. cit., p. 13.

${ }^{21}$ H. Räisänen, J. Alatalo, K. Krüger Henriksen, T. Israelsson, S. Klinger, op. cit., p. 25.

${ }^{22}$ An unemployed person receives a so-called benefit type I for the first 6 to 12 months of unemployment. Thereafter, the person receives a lump sum means-tested benefit type II. Persons who never made contribution payments but who are deemed capable of working will receive the benefit type II right from the beginning.
} 
into force that provide bonuses for the apprenticeship by less privileged young people ${ }^{23}$.

There have also been continued the implementation of stricter rules of entitlements to benefits (especially for older people). Since 2008, the elderly have had to attempt reintegration as other age groups of the unemployed. In 2009 early-retirement schemes was abolished.

The undertaken, during the Hartz reforms, measures led to reduction of long-term unemployment, and in 2010 only $20 \%$ of all active labour market programs were directed to long-tem unemployed (in 2005 - that share was $30 \%)^{24}$.

In 2012 next reform of labour market was implemented, which objective was to accelerate the matching process. Placement officers at the employment agencies can apply various measures more flexibly to help the unemployed to find a job.

German authorities - very conscious of building up the economic position based on international exchange are eager to attract foreign direct investment ${ }^{25}$. There is proposed of wide range of economic incentives (like cash grants, interest-reduced loans, Public Guarantees, labour-related incentives, $\mathrm{R} \& \mathrm{D}$ projects incentives) for international companies, which make easier of running the business in Germany.

Labour-related incentives play a significant role in reducing the operational costs incurred by new business. Germany's Federal Employment Agency (Bundesagentur für Arbeit $-\mathrm{BA}^{26}$ ) and the German states offer a range of labour-related incentives programs designed to fit the different companies' needs when building a workforce. They can be divided into four categories:

- recruitment support,

- pre-hiring training,

- wage subsidies,

- on-the-job training.

The above incentives are available throughout Germany, independently of factors such as a company size, industry sector, investment project location.

${ }^{23}$ H. Räisänen, J. Alatalo, K. Krüger Henriksen, T. Israelsson, S. Klinger, op. cit., p. 27.

${ }^{24}$ Ibidem, p. 28.

25 Between 2007 and 2011, FDI Markets in Germany recorded a total of 3,535 investment projects from around 3,000 foreign companies. With 834 projects, 2011 proved to be the most successful year on record - with Germany placing fifth internationally in terms of FDI project attracted. Germany Trade\&Invest, Economic Overview..., op. cit.

${ }^{26}$ The Federal Employment Agency (Bundesagentur für Arbeit-BA) is the largest provider of labour market services in Germany with a network of more than 700 agencies and branch offices nationwide. The Federal Employment Agency, http://www.arbeitsagentur.de (12.07.2013). 
Programs can be carried out and adjusted by the local job canter according to investors needs.

Table 2. Labour-related incentives Programs Offers in Germany in 2013

\begin{tabular}{|c|c|c|c|}
\hline RECRUITMENT SUPPORT & PRE-HIRING TRAINING & WAGE SUBSIDIES & ON-THE-JOB TRAINING \\
\hline \multicolumn{4}{|c|}{ Program Offerings } \\
\hline $\begin{array}{l}\text { Organization and support } \\
\text { of recruitment process. }\end{array}$ & $\begin{array}{l}\text { Organization of training co- } \\
\text { urses for unemployed can- } \\
\text { didates. }\end{array}$ & $\begin{array}{c}\text { Provided for employment } \\
\text { of (long-term) unemployed } \\
\text { candidates. }\end{array}$ & $\begin{array}{c}\text { Subsidies for further tra- } \\
\text { ining measures within } \\
\text { a company. }\end{array}$ \\
\hline \multicolumn{4}{|c|}{ Eligible Costs } \\
\hline $\begin{array}{l}\text { job vacancy advertisements, } \\
\text { pre-selection of candidates, } \\
\text { assessment centers. }\end{array}$ & $\begin{array}{l}\text { trainee labour costs, trai- } \\
\text { ning course costs. }\end{array}$ & $\begin{array}{c}\text { wage costs, social security } \\
\text { contributions. }\end{array}$ & complete training costs. \\
\hline \multicolumn{4}{|c|}{ Possible Promotion Rates } \\
\hline $\begin{array}{l}\text { up to } 100 \% \text { of eligible } \\
\text { costs subject to local job } \\
\text { center budget. }\end{array}$ & $\begin{array}{c}\text { up to } 100 \% \text { of eligible } \\
\text { costs for a training period } \\
\text { of up to } 3 \text { months, em- } \\
\text { ployment contracts are not } \\
\text { required. }\end{array}$ & $\begin{array}{l}\text { up to } 50 \% \text { of eligible costs } \\
\text { for up to } 12 \text { months, the } \\
\text { employer must guarantee } \\
\text { long-term employment con- } \\
\text { tracts issued after the appli- } \\
\text { cation for wage subsidies. }\end{array}$ & $\begin{array}{c}\text { up to } 50 \% \text { of eligible costs, } \\
\text { EU notification required } \\
\text { for costs exceeding EUR } 2 \\
\text { million. }\end{array}$ \\
\hline \multicolumn{4}{|c|}{ Managing Authority } \\
\hline $\begin{array}{l}\text { Local job centers of the Fe- } \\
\text { deral Employment Agency. }\end{array}$ & $\begin{array}{l}\text { Local job centers of the Fe- } \\
\text { deral Employment Agency. }\end{array}$ & $\begin{array}{l}\text { Local job centers of the Fe- } \\
\text { deral Employment Agency. }\end{array}$ & $\begin{array}{l}\text { Appropriate Federal State } \\
\text { Labour Ministry. }\end{array}$ \\
\hline
\end{tabular}

Source: Germany Trade\&Invest, Investment Guide to Germany, Berlin 2013, p. 45.

Another action, originated from Hartz reforms, which has been continued after them, is a significant increase in the number of employment agencies providing appropriate personnel at short notice ${ }^{27}$. Since 2012 the German temporary employment sector is subject to statutory hourly minimum wages.

\section{POSSIBILITIES OF IMPLEMENTATION IN POLAND OF THE SELECTED GERMAN LABOUR MARKET SOLUTIONS}

Social and economic conditionings in Poland are different than in Germany, which in the context of labour market influences mainly create the disparity in the level of labour demand. However, Poland faces comparable, like in Germany, problems of labour supply as structural unemployment and unfavourable demographic changes.

${ }^{27}$ Germany Trade\&Invest, Investment Guide to Germany, Berlin 2013, p. 62. 
Looking for good practices in area of active labour market policy, benchmarking ${ }^{28}$ of labour market institutions' organisational structures and tools of active labour market programs, is very common in the European Union countries $^{29}$.

German experiences show that simultaneously with deregulation of labour market and extension the motivation system for the unemployed and economically passive to work, there should be implemented the changes of social security system as well as wider range of enabling policies (tools supported employment of those staying without work) ${ }^{30}$.

Selected solutions of German labour market policy, which seem to be worth and possible for application in Poland are listed below:

- reform of social benefits system, which follows the rules of workfare state $^{31}$ and assures the social transfers for those professionally active;

- profiling of the unemployed ${ }^{32}$ - which allows for early identification of long-term unemployment threat and creation of an individual offer; the main difficulty (also for German labour market institutions) is determining the precise groups of clients and later on an accurate qualifying the clients to the selected groups ${ }^{33}$;

- organisational reform of labour market institutions - creation of onestep agencies (in Germany they are functioning for the long-term unemployed) and computerisation of some services;

- greater impact on professional counselling in active labour market policy and the increase of the number of counsellors in the local Job Centers;

- supporting entrepreneurship and self-employment as an alternative for unemployment by decreasing the tax burden for new businesses;

${ }^{28}$ Benchmarking tactics was also used by the Hartz Comission as there was appointed special benchmarking group, which recommended the solutions successfully used in different OECD countries. J. Nadolska, op. cit., p. 259.

${ }^{29}$ Compare: Z. Wiśniewski, Niektóre aspekty polityki zatrudnienia i rynku pracy w Unii Europejskiej. Benchmarking w polityce rynku pracy, [in:] J. Orczyk (ed.), Dylematy zatrudnienia w warunkach postepujacej integracji Polski z Uniq Europejskq, Poznań 2001, pp. 33-36.

30 J. Nadolska, op. cit., p. 261.

31 M. Boni (ed.), Polska 2030 - wyzwania rozwojowe, Warszawa 2009, p. 4.

32 In Poland the tool (computer application - PROFIL) for profiling of the unemployed has already been made by scientist from Nicolaus Copernicus University but so far it has not been used widely by Polish Job Centers.

${ }_{33}$ M. Szylko-Skoczny, Zmiana podejścia do polityki rynku pracy w RFN - reformy Hartza, [in:] L.K. Gilejko, B. Błaszczyk (ed.), Polityka rynku pracy. Doświadczenia europejskie i polskie, Pułtusk 2008, s. 75. 
- better adjustment of educational offer toward labour market demand by promoting vocational education ${ }^{34}$ and cooperation between institutions of secondary, tertiary education and business sector.

\section{CONCLUSIONS}

The fundamental reforms made in Germany to the labour market in recent years have created flexible working models which correspond with the requirements of the modern marketplace.

Summarizing, the main objectives to obtain by conducted legal and organizational actions in the Hartz reforms were:

- increasing effectiveness and efficiency of labour market services and policy measures;

- activation of the unemployed by the implementation of the principle "rights and obligations";

— fostering employment demand by labour market deregulation.

Implementation of many German solutions is difficult in Poland because of lower labour demand, which determines the number of vacancies. Moreover, Polish labour market is inflexible and it is crucial to deregulate it mainly in area of dissemination of elastic forms of employment.

On the other hand benchmarking of many German labour market reforms, connected with active labour market policy faced toward labour supply can contribute to better usage of Polish human capital. Inactivity of the significant part of Polish labour force is mainly connected with the social security benefits system as well as ineffective labour market institutions. The Polish benefits system often discourages the unemployed to look for a job as they lost the benefits entering the labour market. The efficient set of rights and duties is necessary to implement for rationalization the public spending in that area. It is also crucial to increase effectiveness of Polish labour market services and policy measures by smart active labour market programs adjusted to the target groups of the unemployed.

${ }^{34}$ In Poland good solutions in area of vocational education were set up by the Reform from 2011/2012 of building a new qualification system based on the learning outcomes. It supports vocational mobility and makes easier to change a profession, through „building blocks” of qualifications. 


\section{BIBLIOGRAPHY}

Boni M. (ed.), Polska 2030 - wyzwania rozwojowe, Warszawa 2009.

Eurostat, http://epp.eurostat.ec.europa.eu (08.07.2013).

Germany Trade\&Invest, Economic Overview Germany: Market, Productivity, Innovation, Issue 2013, Berlin 2012.

Germany Trade\&Invest, Investment Guide to Germany, Berlin 2013.

Jacobi L., Kluve J., Before and after the Hartz reforms: the performance of active labour market policy in Germany, Forschungsinstitut zur Zukunft der Arbeit, Discussion, Paper No. 2100/2006.

Karlson N., Lindberg H., Corporate cartels and challenges to European labour market models, „Revista Internacional de Organizaciones”, No. 9/2012.

Kemmerling A., Bruttel O., New politics in German labour market policy? The implications of the recent Hartz reforms for the German welfare state, Wissenschaftszentrum Berlin für Sozialforschung, Discussion Paper SP I 101/2005.

Nadolska J., Rynek pracy w procesie przeksztatceń państwa socjalnego we wspótczesnych Niemczech, Oficyna Wydawnicza ASPRA-JR, Warszawa 2010.

Räisänen H., Alatalo J., Krüger Henriksen K., Israelsson T., Klinger S., Labour Market Reforms and Performance in Denmark, Germany, Sweden and Finland, Employment and Entrepreneurship 19/2012, Ministry of Employment and the Economy, Helsinki 2012.

Smandek I.M., Nagel K., Polityka rynku pracy i źródta jej finansowania, Wydawnictwo Uniwersytetu Ekonomicznego w Katowicach, Katowice 2010.

Szylko-Skoczny M., Zmiana podejscia do polityki rynku pracy w RFN - reformy Hartza, [in]: L.K. Gilejko, B. Błaszczyk (ed.), Polityka rynku pracy. Doświadczenia europejskie i polskie, Pułtusk 2008.

The Federal Employment Agency, http://www.arbeitsagentur.de (12.07.2013).

Wiśniewski Z., Niektóre aspekty polityki zatrudnienia i rynku pracy w Unii Europejskiej. Benchmarking w polityce rynku pracy, [in]: J. Orczyk (ed.), Dylematy zatrudnienia w warunkach postęujacej integracji Polski z Unia Europejska, Poznań 2001. 